\title{
Lack of Effect of Chronic Antidepressant Treatment on Gs and Gi $\alpha$-Subunit Protein and mRNA Levels in the Rat Cerebral Cortex
}

\author{
Masoumeh Emamghoreishi, M.Sc., Jerry J. Warsh, M.D., Ph.D., David Sibony, M.Sc., \\ and Peter P. Li, Ph.D.
}

\begin{abstract}
Experimental evidence indicates that chronic antidepressant treatment in rats modifies the central nerous system $\beta$-adrenoceptor signaling pathony at multiple sites including receptor, G-protein, adenylyl cyclase, and protein kinase A. In the present study, we examined the postreceptor effect of antidepressant trentment on the protein and mRNA levels of stimulatory and inhibitory $G$ protein $\alpha$-subunits $\left(G \alpha_{s}\right.$ and $\left.G \alpha_{i}\right)$ and $\beta$-subunits in rats infused continuonsly with aarions antidepressants for 21 days. Chronic treatment with tricyclic (desipramine and annitriptyline') and monoanine oxidase inhibiting (tranylcypromine) antidepressants did not significantly
\end{abstract}

KFY WORDS: Desipramine; Amitriptyline; Tramylcypromine; G proteins; $\beta$-adrenoceptor

Although numerous studies have examined the effects of antidepressants on the central nervous system (CNS) neurotransmitter metabolism, turnover, and receptor sensitivity, the molecular mechanism(s) of action underlying their therapeutic effects is not clearly understood. Preclinical studies in animals indicate that alteration in the CNS noradrenergic system is one of the most consistent biochemical effects shared by most clinically effec-

From the Section of Biochemical P'svchiatry (ME, JJW, DS, Pl'L), Clarke Institute of Psychiatry, Departments of Pharmacology (ME, JJW, PPL) and Psychiatry (JJW, PlP.), Institute of Medical Sciences (JJW), University of Toronto, Toronto, Ontario, Canada.

Addre's correspondence to: P'eter ['. Li, P'h. L)., Section of Biochemical Psychiatry, Clarke Institute of Psichiatry, 250 College Street. Toronto, Ontario, Canada, MST 1RS.

Received June 29, 1995; revised October 5. 1995; rccepted October 10), 1995 . affect the immunoreactivity levels of $G \alpha_{s}$ (both 45 - and 52-kDa species), $G \alpha_{i 1}, G \alpha_{i 2}, G \beta_{36}$, and $\beta_{35}$ in rat cerebral cortex. Similarly, the levels of mRNA encoding these $G$ protein subunits remained unchanged subsequent to these drug treatments. In contrast, cortical $\beta$-adrenoceptor number was significantly decreased by these treatments. These results suggest that the adaptive changes of rat cerebral cortical $\beta$-adrenoceptor-adenylyl cyclase system often seen after chronic antidepressant treatment are not accompanied by changes in the abundance and gene expression of $G \alpha_{i}, G \alpha_{i}$, or $G \beta$ proteins.

[Neuropsychopharmacology 15:281-287, 1996]

tive antidepressants (Charney et al. 1981). Thus, chronic antidepressant treatment in rats reduces the responsiveness of the $\beta$-adreneroceptor-coupled adenylyl cyclase system, which is associated, in most cases, with downregulation of $\beta$-adrenoceptors (Charney et al. 1981). However, several reports suggest that alterations in $\beta$-adrenoceptor density cannot entirely account for the decreases in neurotransmitter-stimulated adenylyl cyclase activity. In rats chronically treated with desipramine, the decrease in isoproterenol-stimulated adenylyl cyclase activity in cortical membranes is more rapid and greater than the reduction in $\beta$-adrenoceptor number, suggesting that decreased receptor density is not responsible for the early development of desensitization of $\beta$-adrenoceptor-linked adenylyl cyclase response during desipramine therapy (Okada et al. 1986). Moreover, chronic treatment of rats with mianserin or zimelidine reduces norepinephrine (NE)-stimulated cyclic adenosine monophosphate (cAMP) production with- 
out affecting $\beta$-adrenoceptor density (Mishra et al. 1980). Taken together, the dissociation of the effects of antidepressant treatment on the functional responsivity from changes in $\beta$-adrenoceptor density suggest that additional postreceptor changes in this signaling pathway may be related to their therapeutic action.

As guanine nucleotide binding proteins ( $G$ proteins) play a pivotal role in coupling neuroreceptors to intracellular effector systems including adenylyl cyclase (Gilman 1987), they represent one of the possible postreceptor target sites at which antidepressant drugs could act to desensitize the $\beta$-adrenoceptor signaling pathway after chronic administration. In support of this notion, chronic desipramine treatment of rats has been shown to attenuate the isoproterenol-induced stimulation of adenylyl cyclase by Gpp[NH]p (Okada et al. 1986). This, together with the findings that isoproterenolinduced increases in $\left[{ }^{3} \mathrm{H}\right] \mathrm{GTP}$ binding to rat cerebral cortical membranes were reduced subsequent to chronic treatments with imipramine, clomipramine, and clorgyline (Avissar and Schreiber 1992), suggested that the coupling between $\beta$-adrenoceptor and the stimulatory $G$ protein (Gs) may be impaired. On the other hand, a number of studies have examined changes in Gpp[NH]p-, $\mathrm{NaF}$-, or forskolin-stimulated adenylyl cyclase activity in rat cortical membranes after chronic antidepressant treatment (Menkes et al. 1983; Duman et al. 1985; Newman et al. 1986; Okada et al. 1986; Ozawa and Rasenick $1989,1991)$. Because of the variations in results among these studies, it is not certain whether chronic antidepressant treatment modulates the coupling between Gs and adenylyl cyclase.

Recently, a number of studies have indicated that heterologous desensitization of the adenylyl cyclase response in a number of cell lines is accompanied by changes in the cellular levels of Gs and/or inhibitory G protein, $\mathrm{Gi}$, which stimulates and inhibits adenylyl $\mathrm{cy}$ clase activity, respectively (Milligan 1993; Williams et al. 1993). In light of these findings, the present study was undertaken to examine whether the chronic effect of tricylic and monoamine oxidase (MAO) inhibiting antidepressants on $\beta$-adrenergic signaling pathway may be, in part, due to alterations in the abundance and/or gene expression of $G$ protein $\alpha$-subunits that regulate adenylyl cyclase activity. Because $G$ proteins are heterotrimeric comprised of $\alpha, \beta$, and $\gamma$ subunits, and $\beta \gamma$ dimers are known to regulate adenylyl cyclase activity (Clapham and Neer 1993), we also examined whether the abundance and mRNA levels of $\beta$-subunits are altered by chronic antidepressant treatment.

\section{MATERIALS AND METHODS}

\section{Chemicals}

[125I]-iodopindolol (2200 Ci/mmol), [ $\left.{ }^{32} \mathrm{P}\right] \mathrm{dCTP}(3000$ $\mathrm{Ci} / \mathrm{mmol}$ ), and the $\mathrm{G}$ protein antisera $\mathrm{RM} / 1$ (specific to
$\mathrm{G} \alpha_{\mathrm{s}-\mathrm{s}}$ and $\left.\mathrm{G} \alpha_{\mathrm{s}-1}\right), \mathrm{AS} / 7\left(\mathrm{G} \alpha_{\mathrm{i} 1}\right.$ and $\left.\mathrm{G} \alpha_{\mathrm{i} 2}\right)$, SW $/ 1\left(\mathrm{G} \beta_{1}, \mathrm{G} \beta_{2}\right.$, $\mathrm{G} \beta_{3}$, and likely $G \beta_{4}$ ) were purchased from NEN Dupont (Boston, MA). Desipramine $\mathrm{HCl}$, amitriptyline $\mathrm{HCl}$, tranylcypromine $\mathrm{HCl}$, and dithiothreitol were obtained from Sigma Chemical Company (St. Louis, MO). Protein A-Horseradish peroxidase was purchased from Bio-Rad (Hercules, CA), RNA ${ }^{\text {zol }}$ B solution from ID Labs Inc. (London, Ontario), and the Enhanced Chemiluminescence (ECL) western blotting detection system was from Amersham Canada (Oakville, Ontario). All other reagents were acquired either as analytic or molecular biologic grade from commercial sources.

\section{Animals and Drug Treatments}

Male Wistar rats (Charles River, St. Constant, Quebec) weighing initially 220 to $250 \mathrm{~g}$ were housed individually at $21 \pm 1^{\circ} \mathrm{C}$ and maintained on a 12-hour light-dark cycle with free access to rat chow and water. After acclimatization for 1 week, they were assigned randomly to treatment conditions, anesthetized with methoxyflurane, and implanted intraperitoneally with an osmotic minipump (model 2ML4, Alza Corp., CA) delivering desipramine (12 mg/kg per day), amitriptyline (11 mg/ $\mathrm{kg}$ per day), tranylcypromine (10 $\mathrm{mg} / \mathrm{kg}$ per day), or saline. The incisions were sutured, and after recovery the animals were returned to their home cages. Each of the four groups comprised 10 rats. After chronic administration (21 days) of drugs, animals were decapitated and whole brains rapidly removed, rinsed in ice-cold saline, and gently blotted dry. Whole cerebral cortices were then dissected out and frozen at $-70^{\circ} \mathrm{C}$ until time of analysis. At the beginning of the experiment, there was no difference in weights of control ( $309 \pm 6 \mathrm{~g}$; mean \pm SEM, $n=10$ ) versus antidepressant drug treatment groups (desipramine: $307 \pm 6$; amitriptyline: $313 \pm 7$; tranylcypromine: $308 \pm 8 \mathrm{~g} ; n=10$ in each group). However, animals receiving desipramine and tranylcypromine had gained significantly less weight (desipramine: $61 \pm 6$; tranylcypromine: $37 \pm 4$ g; $p<.05$ ) compared to controls $(86 \pm 6 \mathrm{~g})$ during the treatment period. The mean weights for the amitriptyline-treated rats and control rats on day 21 were $398 \pm 11 \mathrm{~g}$ and $395 \pm 7 \mathrm{~g}$, respectively, and were not significantly different. Animals used in this study were cared for in accordance with the guidelines of the Canadian Council on Animal Care, and the protocols were approved by the Clarke Institute of Psychiatry Animal Care Committee.

\section{Membrane Preparation}

Cerebral cortex from each animal was homogenized in 10 volumes of ice-cold buffer $(0.25 \mathrm{~mol} / \mathrm{L}$ sucrose, 25 $\mathrm{mmol} / \mathrm{L}$ Tris- $\mathrm{HCl}, \mathrm{pH} 7.4)$ using a glass homogenizer fitted with a Teflon pestle at $800 \mathrm{rpm}$ (15 strokes/sam- 
ple). The homogenates were centrifuged $(1,000 \mathrm{~g}, 10$ minutes, $4^{\circ} \mathrm{C}$ ) and the resulting supernatants recentrifuged at $12,000 \mathrm{~g}$ for 20 minutes at $4^{\circ} \mathrm{C}$. The pellets containing crude membranes were then resuspended in ice-cold Tri-HC1 buffer $(25 \mathrm{mmol} / \mathrm{L}, \mathrm{pH} 7.4)$ and stored at $-70^{\circ} \mathrm{C}$. Protein was determined according to Bradford (1976) using bovine serum albumin (BSA) as standard.

\section{$\beta$-Adrenoceptor Binding Assay}

$\left[{ }^{125} \mathrm{I}\right]$-iodopindolol binding was performed according to the method described by Ozawa et al. (1990). Briefly, 50 $\mu \mathrm{g}$ of membrane protein were incubated in triplicate for 40 minutes at $30^{\circ} \mathrm{C}$ in a total volume of $0.2 \mathrm{ml}$ of Tris$\mathrm{HCl}(25 \mathrm{mmol} / \mathrm{L}, \mathrm{pH} 7.4), 5 \mathrm{mmol} / \mathrm{L} \mathrm{MgCl}, 120$ $\mathrm{mmol} / \mathrm{L} \mathrm{NaCl}, 1 \mathrm{mmol} / \mathrm{L}$ ascorbic acid, and 0.38 $\mathrm{nmol} / \mathrm{L}\left[{ }^{125} \mathrm{I}\right]$-iodopindolol. The reaction was terminated by the addition of $3 \mathrm{ml}$ of ice-cold stopping buffer containing $10 \mathrm{mmol} / \mathrm{L}$ Tris- $\mathrm{HCl}(\mathrm{pH} \mathrm{7.4)}$ and 150 $\mathrm{mmol} / \mathrm{L} \mathrm{NaCl}$ followed by rapid filtration under vacuum through Whatman GF/B filters. The filters were then washed three more times with $3 \mathrm{ml}$ of stopping buffer, and the radioactivity retained on the filters was counted in a Beckman Gamma 5300B counter (counting efficiency $70 \%$ ). Nonspecific binding was determined using $0.1 \mathrm{mmol} / \mathrm{L}(-)$-isoproterenol.

\section{SDS-PAGE and Immunoblot Analysis of G Protein Subunits}

Electrophoresis of cortical membrane G protein subunits through polyacrylamide gels and immunoblot analysis was performed essentially as described previously (Young et al. 1993; Wong et al. 1994). For separation of $\mathrm{G} \alpha$, isoforms, the resolving gels were composed of $10 \%$ acrylamide and $0.26 \%$ bisacrylamide $(w / v)$. Separation of $G \alpha_{i 1}$ and $G \alpha_{i 2}$ or $G \beta_{36}$ and $G \beta_{35}$ was achieved using resolving gels containing $12.5 \%$ acrylamide, $0.062 \%$ bisacrylamide, and $4.2 \%$ glycerol. Gels were run at $200 \mathrm{~V}$ for 1 hour, and the resolved proteins were transferred electrophoretically to polvvinylidene difluoride (PVDF) membranes using a semi-dry transblot apparatus (Trans-Blot SD, Bio-Rad). Membranes were probed sequentially with primary (RM/1, 1:2000 dilution; AS/7, 1:5000 dilution; or SW/1, 1:5000 dilution) and secondary (protein A-HRP, 1:3000 dilution) antibodies. The immunoreactive bands were detected with the ECL western blot detection system and analyzed using a computerized image analysis system (MCID, Imaging Research Inc., St. Catharines, ON). The optical density for each experimental sample band was normalized against the value obtained for a pooled rat cortex reference standard run within each blot to control for interblot variance.

\section{Analysis of mRNA by Northern Blotting}

Total RNA from cerebral cortex was isolated by the guanidinium thiocyanate/phenol/chloroform method described by Chomczynski and Sacchi (1987). Briefly, cerebral cortex was homogenized in the RNA ${ }^{\text {zol }} \mathrm{B}$ solution ( $2 \mathrm{ml}$ per $100 \mathrm{mg}$ tissue), and extracted with chloroform. The samples were precipitated with ethanol and resuspended in diethylpyrocarbonate-treated water. RNA in each sample was quantified spectrophotometrically at $260 \mathrm{~nm}$, and purity estimated by the ratio of $260 / 280$ $\mathrm{nm}(\sim 1.6$ to 1.8$)$. The yield of total cortical RNA normalized to tissue weight did not differ significantly in rats treated chronically with amitriptyline $(0.68 \pm 0.02$ $\mu \mathrm{g}$ RNA/mg tissue; $n=8)$, desipramine $(0.70 \pm 0.04 ; n=$ $8)$, and tranylcypromine $(0.76 \pm 0.03 ; n=8)$ when compared with controls $(0.71 \pm 0.03 ; n=8)$. Total RNA was fractionated on a $1 \%$ agarose formaldehyde gel, transferred to GeneScreen Plus membranes, and probed with random primer [ $\left.{ }^{32} \mathrm{P}\right]$-labeled $\mathrm{G} \alpha_{\mathrm{s}}, \mathrm{G} \alpha_{\mathrm{i} 1}, \mathrm{G} \alpha_{\mathrm{i} 2}, \mathrm{G} \beta_{1}$, and $G \beta_{2}$ cDNA probes, as described previously (see $\mathrm{Li}$ et al. 1993). The levels of $G$ protein subunit mRNA were analyzed using an MCID imaging analysis system and normalized against cyclophilin mRNA, determined by reprobing the same membrane with [32P]-labeled cyclophilin cDNA.

\section{Statistical Analysis}

Statistical analysis of the data was performed using either Student's $t$-test or univariate analysis of variance (ANOVA) followed by Tukey's test for post hoc comparison of group means. $P$ values less than .05 were considered statistically significant.

\section{RESULTS}

Immunoblots of rat cerebral cortical membranes obtained with antiserum RM/1 detected two immunoreactive bands of approximately 45 and $52 \mathrm{kDa}$, representing the $G \alpha_{s-s}$ and $G \alpha_{s-1}$ isoforms, respectively (Figure 1). Immunodetection with the AS/7 antiserum, which recognizes both $G \alpha_{i 1}$ and $G \alpha_{i 2}$, identified two polypeptides of 41 and $40 \mathrm{kDa}$, after resolution of the cortical membranes in $12.5 \%(\mathrm{w} / \mathrm{v})$ acrylamide SDSPAGE as described by Tanfin et al. (1991). These comigrated with respective baculovirus-expressed recombinant $G \alpha_{i 1}$ and $G \alpha_{i 2}$ (gifts from M. Dennis, Montreal) reference standards (data not shown). Under the same SDS-PAGE used to resolve $G \alpha_{i 1}$ and $G \alpha_{i 2}$ subtypes, western blot analysis with antiserum SW/1 directed against the common $\beta$-subunits revealed two immunoreactive bands of 36 and $35 \mathrm{kDa}$, designated herein as $\mathrm{G} \beta_{36}$ and $G \beta_{35}$ subunits, respectively (Figure 1). As illustrated in Figure 2, there were no significant differ- 
ences in the immunoreactivity levels of $G \alpha_{s-s}, G \alpha_{s-1}$, $G \alpha_{i 1}, G \alpha_{i 2}, G \beta_{36}$, and $G \beta_{35}$ subunits in rats treated chronically with amitriptyline, desipramine, and tranylcypromine compared with controls.

We also investigated whether chronic antidepressant treatment could alter the transcript levels of these $G$ protein subunits. Northern blot analysis of rat cortex (Figure 3) showed that the $G(x$, probe hybridized to a $1.8 \mathrm{~kb}$ mRNA species that encodes the two forms of $\mathrm{G} \alpha_{s}$. The $\mathrm{G} \alpha_{i 1}$ probe hybridized to a $3.4 \mathrm{~kb}$ mRNA species, whereas the probe for $G \alpha_{i 2}$ revealed a band of 2.4 $\mathrm{kb}$. The probes for $G \beta_{1}$ and $G \beta_{2}$ hybridized to a mRNA species at 2.9 and $1.8 \mathrm{~kb}$, respectively. These findings are in agreement with the known size of the mRNAs previously reported for the respective $G$ protein subunits (Jones and Reed 1987; Levine et al. 1990; Li et al. 1993). Quantitative analysis of northern blots from antidepressant-treated and control rats revealed no statistically significant alterations in the steady-state levels of $G \alpha_{s}$, $G \alpha_{11}, G \alpha_{i 2}, G \beta_{1}$, and $G \beta_{2}$ mRNA in rat cortex after longterm treatment with amitriptyline, desipramine, and tranylcypromine (Figure 4).

To verify the effectiveness of chronic drug administration, brain $\beta$-adrenoceptor binding was also determined. Scatchard analysis of the 125 -iodopindolol saturation isotherms in rat cortical membranes revealed a single population of receptors with a $K_{d}$ of $80 \mathrm{pmol} / \mathrm{L}$

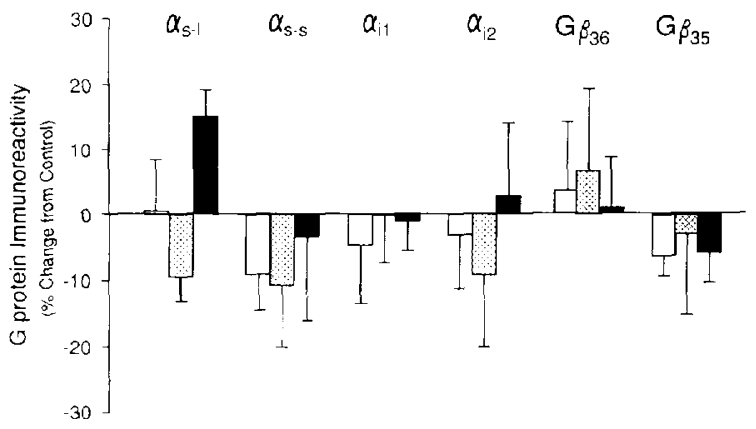

Figure 2. Effect of chronic administration of amitriptyline (AMI, open bars), desipramine (DMl, hatched bars), and tranylcypromine (TCP, dark bars) on the immunoreactivity levels of $G$ protein subunits in rat cortex. The results are expressed as percent change from control for each subunit, each bar represents the mean \pm SEM of five to 10 animals.

and a $B_{\max }$ of $70 \mathrm{fmol} / \mathrm{mg}$ protein (data not shown). In cortical membrane preparations for rats chronically infused with amitriptyline, desipramine, and tranylcypromine, there was a significant decrease $(p<.05)$ in the specific binding of ${ }^{125} \mathrm{I}$-iodopindolol $(0.38 \mathrm{nmol} / \mathrm{L})$ compared with controls (control: $95 \pm 10 \mathrm{fmol} / \mathrm{mg}$ protein; amitriptyline: $62 \pm 4$; desipramine: $30 \pm 1$; and tranylcypromine: $33 \pm 1 ; n=6$ in each group).

\section{DISCUSSION}

\section{A $\quad$ B $\quad$ C $\quad$ D}
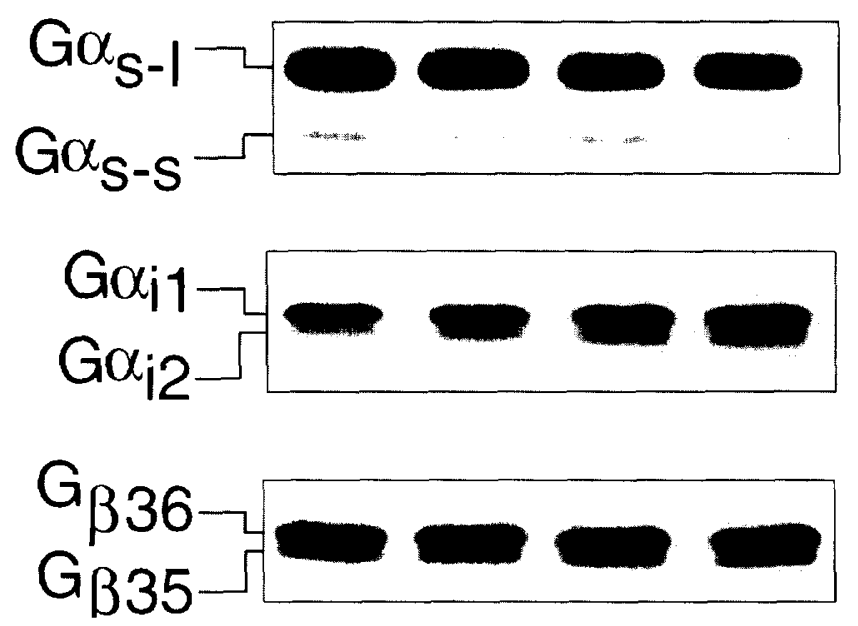

Figure 1. Representative luminograms of immunolabeling of $G\left(\alpha_{s}, G\left(\alpha_{i}\right.\right.$, and $G, \beta$ in rats chronically infused with amitriptyline (hane B), desipramine (lan C), tranylcypromine (lan' $D$ ), and saline (hant $A$ ) for 21 days. Cerebral cortical membrane's were subjected to SDS-PACE, electrotransferred to PVDF membranes, and reacted with rabbit polyclonal antisera specific for $G x_{s}(R M / 1), G\left(x_{i}(A S / 7)\right.$, and $G \beta(S W / 1)$, as described in the text. The film was intentionally overexposed to show the $G \alpha_{s-.}$. For quantitation of $G \alpha_{s-1}$, blots with less exposure were used.
This study demonstrates that chronic treatment of rats with different categories of antidepressants including desipramine (NE uptake inhibitor), amitriptyline (mixed $\mathrm{NE}$ / serotonin(5HT) uptake inhibitor), and tranylcypromine (MAO inhibitor) fails to alter the protein and mRNA levels of $G \alpha_{s}, G \alpha_{i}$, and $G \beta$ subunits. It appears unlikely that the drug dosage, schedule, and route of administration used in the present study were insufficient to produce $G$ protein changes as the same treatment reduced the density of cortical $\beta$-adrenoceptors, a consistent finding in rats treated chronically with antidepressants (Charney et al. 1981). Thus, our results suggest that the adaptive changes of the $\beta$-adrenoceptor signaling pathway in rat cerebral cortex, often seen after chronic antidepressant treatment do not involve regulation in the abundance or expression of $G \alpha_{s}, G \alpha_{i}$, and $G \beta$ subunits.

Using a competitive enzyme-linked immunosorbent assay (ELISA), Lesch et al. (1991) showed that the amount of cortical $G \alpha_{s}$ and $G \alpha_{i}$ is not altered in rats after chronic treatment with desipramine, imipramine, clomipramine, and clorgyline. Because ELISA could not distinguish different isoforms of $\mathrm{G}$ protein $\alpha$-subunits (e.g., $G \alpha_{s-s}$ and $G \alpha_{s-1}$ ) or subtypes like $G \alpha_{i 1}$ and $G \alpha_{i 2}$, it is possible that alteration in one subtype or isoform may be obscured by the lack of change (or a change in 


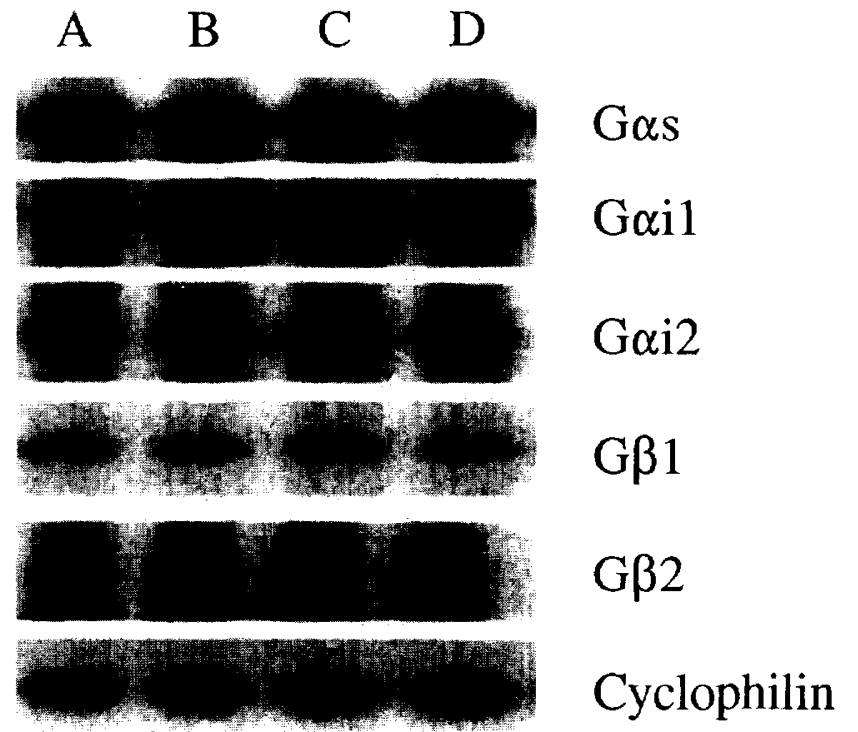

Figure 3. Autoradiograms from Northern blot hybridization of total RNA extracted from cerebral cortex of rat treated chronically with saline (lan' $A$ ), amitriptyline (lane $B$ ), desipramine (lane $C$ ), and tranylcypromine (lane $D$ ) and hybridized with ${ }^{32}$ P-labeled CDNA probes specific for $G\left(x_{s}\right.$, $G \alpha_{i 1}, G \alpha_{i 2}, G \beta_{1}, G \beta_{2}$, or cyclophilin as described in the text.

opposite direction) when they are measured without resolution. In the present study, we used an immunoblotting assay, which permits measurement of these $G$ protein subunits individually once they are adequately resolved on acrylamide SDS-PAGE, and showed that the immunoreactivity levels of $G \alpha_{s-s}, G \alpha_{s-1}, G \alpha_{i 1}, G \alpha_{i 2}$, $G \beta_{36}$, and $G \beta_{35}$ were unchanged after chronic treatment with representative tricyclic and $\mathrm{MAO}$ inhibiting antidepressants. These results, confirm and extend earlier

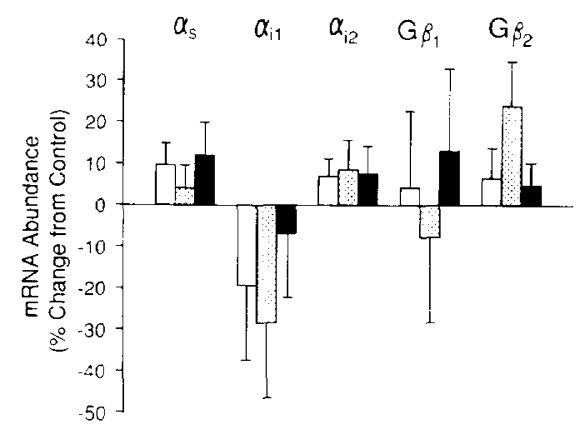

Figure 4. Effect of chronic administration of amitriptyline (AMI, open bars), desipramine (DMI, hatchet bars), and tranylcypromine (TCP, dark hars) on the levels of G protein subunit mRNA in rat cortex. Total RNA was isolated and analyzed for $G \alpha_{4}, G \alpha_{i 1}, G \alpha_{i 2}, G \beta_{1}$, and $G \beta_{2}$ mRNA by Northern blot hybridization as described in the text. Levels of $G$ protein subunits $\mathrm{mRNA}$ were normalized against the cyclophilin mRNA signals, and the results are expressed as percent change from control for each $G$ protein subunit. Each bar represents the mean $=$ SEM of five to eight animals. work by Lesch et al. (1991), suggesting that chronic antidepressant treatment has little or no effect on $\mathrm{Gs}$ and $\mathrm{Gi}$ $\alpha$-subunits levels in rat cerebral cortex. However, we cannot absolutely exclude the possibility that chronic antidepressant treatment may alter the expression of $G$ protein subunit in specific subfields within the cortex or other limbic brain regions. Additional studies using quantitative immuncytochemical techniques will be required to assess this possibility.

Several lines of evidence suggest the function of $G$ protein linked to adenylyl cyclase activation might be altered after chronic antidepressant treatment. A significant increase of Gpp[NH]p-, NaF-, and forskolin-activated adenylyl cyclase activity was found in rat cortical membranes after chronic antidepressant and electroconvulsive shock treatment (Menkes et al. 1983; Newman et al. 1986; Ozawa and Rasenick 1989, 1991). However, Duman et al. (1985) and Okada et al. (1986) reported that Gpp[NH]p- or NaF-activated adenylyl cyclase activity was not altered after chronic administration of desipramine or imipramine. Furthermore, the inhibition of adenylyl cyclase by Gpp[NH]p was not affected by chronic treatment with desipramine, amitriptyline, iprindole, or electroconvulsive shock (Ozawa and Rasenick 1989, 1991). The absence of significant alterations in $G \alpha_{s}$ and $G \alpha_{i}$ levels subsequent to chronic antidepressant treatment in the present study is in line with latter studies, which suggested that neither the function of Gs nor Gi was altered in response to repeated antidepressant treatment (Duman et al. 1985; Okada et al. 1986).

It has been suggested that changes in $\mathrm{G} \alpha_{\mathrm{s}}$ and $\mathrm{G} \alpha_{\mathrm{i}}$ proteins and their mRNAs may not be coordinately regulated in various tissues including brain (Granneman et al. 1990; Li et al. 1993). For this reason, we also measured $G \alpha_{s}, G \alpha_{i 1}, G \alpha_{i 2}, G \beta_{1}$, and $G \beta_{2}$ mRNA levels in cerebral cortex of these same rats after chronic antidepressant treatment. In no cases were the levels of these $G$ protein subunit mRNA altered, suggesting that chronic antidepressant treatment does not affect the dynamics of $\mathrm{G} \alpha_{s}, \mathrm{G} \alpha_{i}$, and $\mathrm{G} \beta$ biosynthesis at the level of gene expression. These findings are in line with the previous reports showing similar levels of $G \alpha_{s}, G \alpha_{i 1}$, and $G \alpha_{i 2}$ mRNA in the cortex of rats treated chronically with imipramine, desipramine, and clomipramine compared with controls (Lesch and Manji 1992).

Whereas both antidepressant drugs and lithium are known to attenuate $\beta$-adrenoceptor-coupled adenylyl cyclase response (Avissar and Schreiber 1992), only lithium is reported to modulate the transcription of genes encoding $G \alpha_{s}$ (Li et al. 1993) and $G \alpha_{i}$ (Colin et al. 1991; Li et al. 1993). Recent findings of elevated cortical $G \alpha_{\mathrm{s}}$ levels in postmortem brain of manic-depressive (Young et al. 1993) but not depressed (Ozawa et al. 1993; Cowburn et al. 1994) patients and the results of the present study highlight the selectivity of lithium regulation of $G$ 
protein gene expression as well as the importance of $G$ proteins in the pathophysiology of manic-depressive illness. However, this does not necessarily preclude $G$ protein involvement in the mechanism of action of antidepressant drugs or in the pathophysiology of depressive illness. It has been shown that $G$ proteins are the targets of a number of cotranslational and posttranslational modifications including ADP-ribosylation, fatty acylation, and phosphorylation, all of which are known to modify the functional status of these transducing proteins (Gilman 1987; Wedegaertner et al. 1995). Because the antisera utilized in this study could not distinguish various modified forms of the same protein, it is not possible to determine the fraction of $\alpha$-subunits that were in a specific state of cotranslational or posttranslational modification. Therefore, it is possible that the degree of cotranslational or posttranslational modification in $G \alpha_{s}$ or $G \alpha_{i}$ is altered after chronic antidepressant treatment, whereas the total amount of these subunits remained unchanged, resulting in altered coupling efficiency between $\beta$-adrenoceptor and Gs, or between Gs and adenylyl cyclase as reported earlier (Okada et al. 1986; Ozawa and Rasenick 1989, 1991). In this regard, it is interesting to note that chronic exposure of $\mathrm{C} 6$ glioma cells with desipramine failed to alter $\mathrm{G} \alpha_{s}$ and $\mathrm{G} \alpha_{i}$ levels but significantly reduced the cholera toxin-catalyzed ADP ribosylation of $\mathrm{G} \alpha_{s}$ (Lesch and Manji 1992). Future research is needed to determine whether one or several of these modifications is regulated by antidepressant drugs or is a contributing factor in the pathogenesis of depression.

\section{ACKNOWLEDGMENTS}

We gratefully acknowledge Drs. R. Reed, M. Levine, and H. Van Tol for the generous gifts of $G$ proteins and cyclophilin cDNA clones, and Dr. M. Dennis for his kind gifts of recombinant $G$ proteins. This work was supported by research grants from the Ontario Mental Health Foundation, Canadian Psychiatric Research Foundation, and Medical Research Council of Canada (PPL). M.E. is the recipient of a studentship from the Iranian Ministry of Health and Medical Education. We' thank Mr. P. Fazzini for assistance with the illustrations.

\section{REFERENCES}

Avissar S, Schreiber G (1992): The involvement of guanine nucleotide binding proteins in the pathogenesis and treatment of affective disorders. Biol Psychiatry 31:435459

Bradford MM (1976): A rapid and sensitive method for quantitation of microgram quantities of protein utilizing the principle of protein-dye binding. Anal Biochem $72: 248-252$

Charney DS, Menkes DB, Heninger GR (1981): Receptor sen- sitivity and the mechanism of action of antidepressant treatment: Implications for the etiology and therapy of depression. Arch Gen Psychiatry 38:1160-1180

Chomczynski P, Sachii N (1987): Single-step method of RNA isolation by acid guanidinium thiocyanate-phenol-chloroform extraction. Anal Biochem 162:156-159

Clapham DE, Neer EJ (1993): New roles for G-protein $\beta \gamma$ dimers in transmembrane signaling. Nature 365:403-406

Colin SF, Chang HC, Mollner S, Pfeuffer T, Reed RR, Duman RS, Nestler EJ (1991): Chronic lithium regulates the expression of adenylate cyclase and Gi-protein $\alpha$-subunit in rat cerebral cortex. Proc Natl Acad Sci USA 88:10634-10637

Cowburn RF, Marcusson JO, Eriksson A, Wiehager B, O'Neill C (1994): Adenylyl cyclase activity and G-protein subunit levels in postmortem frontal cortex of suicide victim. Brain Res 633:297-304

Duman RS, Strada SJ, Enna SJ (1985): Effect of imipramine and adrenocorticotropin administration on the rat brain norepinephrine-coupled cyclic nucleotide generating system: Alterations in alpha and beta adrenergic components. J Pharmacol Exp Ther 234:409-414

Gilman AG (1987): G proteins: Transducers of receptor-generated signals. Ann Rev Biochem 56:615-649

Granneman JG, Haverstick DM, Chaudhry A (1990): Relationship between Gs messenger ribonucleic acid splice variants and the molecular forms of Gs protein in rat brown adipose tissue. Endocrinology 127:1596-1601

Jones, DT, Reed RR (1987): Molecular cloning of five GTPbinding protein CDNA species from rat olfactory neuroepithelium. J Biol Chem 262:14241-14249

Lesch KP, Aulakh CS, Tolliver TJ, Hill JL, Murphy DL (1991): Regulation of $G$ proteins by chronic antidepressant drug treatment in rat brain: Tricyclics but not clorgyline increase Go subunits. Eur J Pharmacol Mol Pharmacol 207:361-364

Lesch KP, Manji HK (1992): Signal-transducing G proteins and antidepressant drugs: Evidence for modulation of $\alpha-$ subunit gene expression in rat brain. Biol Psychiatry $32: 549-579$

Levine MA, Smallwood PM, Moen PT, Helman LJ, Ahn TG (1990): Molecular cloning of $\beta$ subunit, a third form of the $G$ protein $\beta$-subunit polypeptide. Proc Natl Acad Sci USA 87:2329-2333

Li PP, Young LT, Tam YK, Sibony D, Warsh JJ (1993): Effects of chronic lithium and carbamazepine treatment on $G$-protein subunit expression in rat cerebral cortex. Biol Psychiatry 34:162-170

Menkes DB, Rasenick MM, Wheeler MA, Bitensky MW (1983): Guanosine triphosphate activation of brain adenylate cyclase: Enhancement by long-term antidepressant treatment. Science 219:65-67

Milligan G (1993): Agonist regulation of cellular G protein levels and distribution: Mechanisms and functional implications. Trends Pharmacol Sci 14:413-418

Mishra R, Janowsky A, Sulser F (1980): Action of mianserin and zimelidine on the norepinephrine receptor coupled adenylate cyclase system in brain: Subsensitivity without reduction in $\beta$-adrenergic receptor binding. Neuropharmacology 19:983-987 
Newman ME, Solomon H, Lerer B (1986): Electroconvulsive shock and cyclic AMP signal transduction: Effects distal to the receptor. J Neurochem 46:1667-1669

Okada F, Tokumitsu Y, Li M (1986): Desensitization of $\beta$-adrenergic receptor-coupled adenylate cyclase in cerebral cortex after in vivo treatment of rats with desipramine. J Neurochem 47:454-459

Ozawa H, Rasenick MM (1989): Coupling of Gs to rat synaptic membrane adenylate cyclase is enhanced subsequent to chronic antidepressant treatment. Mol Pharmacol 36:803-808

Ozawa H, Rasenick MM, Saito T (1990): Effect of chronic antidepressant administration on beta-adrenergic receptor-GTP binding protein-adenylate cyclase coupling. Biog Amines 7:535-546

Ozawa H, Rasenick MM (1991): Chronic electroconvulsive treatment augments coupling of the GTP-binding protein Gs to the catalytic moiety of adenylyl cyclase in a manner similar to that seen with chronic antidepressant drugs. J Neurochem 56:330-338

Ozawa H, Gsell W, Frolich L, Zochling R, I'antucek F, Beck- mann H, Riederer P (1993): Imbalance of the $G_{s}$ and $G_{i / 0}$ function in post-mortem human brain of depressed patients. J Neural Transm 94:63-69

Tanfin Z, Goureaym I, Milligan G, Harbon S (1991): Characterization of $G$ proteins in rat myometrium: A differential modulation of $\mathrm{G}_{i} 2$ and $\mathrm{G}_{\mathrm{i}} 3$ during gestation. FEBS Lett 278:4-8

Wedegaertner PB, Wilson PT, Bourne HR (1995): Lipid modification of trimeric $G$ proteins. J Biol Chem 270:503-506

Williams RJ, Veale MA, Horne P, Kelly E (1993): Ethanol differentially regulates guanine nucleotide-binding protein $\alpha$ subunit expression in NG108-15 cells independently of extracellular adenosine. Mol Pharmacol 43:158-166

Wong CC, Warsh JJ, Sibony D, Li PP (1994): Differential ontogenetic appearance and regulation of stimulatory $\mathrm{G}$ protein isoforms in rat cerebral cortex by thyroid hormone deficiency. Dev Brain Res 79:136-139

Young LT, Li PP, Kish SJ, Siu KP, Kamble A, Hornykiewicz O, Warsh JJ (1993): Cerebral cortex Gs protein levels and forskolin-stimulated cyclic AMP formation are increased in bipolar affective disorder. J Neurochem 61:890-898 